\title{
Acquiring ICT Competencies Using Computer Based Learning
}

\author{
Johan@Eddy Luaran and Zulkifli Mohamed, Member, IACSIT
}

\begin{abstract}
Studies have shown that the application of information and communication technology (ICT) in classrooms is still at an unsatisfactory level. The purposes of this research are to determine the skill of primary school teachers especially those teaching in rural areas in using IT, and thereafter to develop a multimedia learning package (WEDPI Package). The ICT aspect refers to productivity tools, which include applications for word-processing, electronic spreadsheet, database, presentation and the Internet. This research adopts quantitative approach and an ADDIE model is used in the development of this multimedia learning package. A hands-on test was administered to determine the skill of the teachers. The pre-experimental designs, which were the pre and post tests, were executed to determine if there were any differences in the level of skill among the teachers after using the WEDPI Package. The t-test result shows that there was a significant difference in the achievement of the teachers' scores.
\end{abstract}

Index Terms-Computers, multimedia, primary schools, teacher.

\section{INTRODUCTION}

The development of information and communication technology influences much of Malaysian culture and lifestyle. The application of technology in teaching and learning gives a new paradigm in teacher's teaching techniques. Previous studies have proven that the application of information communication technology (ICT) has been able to revolutionize teachers' teaching techniques and pupils' learning method. Meanwhile the time has come for schools to be informative, creative and wise by applying ICT [1]. Smart Schools were established to give a wide place for computer technology in education system in Malaysia. This move will narrow the digital divide between the rich group capable of using the technology at home and the less wealthy group [2]. This facility could give more opportunity to the students to explore, control and develop various skills and knowledge more effectively and further relate the knowledge with the reality. This would finally be able to produce knowledgeable generations and smart competition to realize the country's vision 2020.

The government's vision to build and develop human capital in the future is very much dependent on the quality of our national education system. Hence, the Education Development Master Plan 2006-2010 has been planned to

Manuscript received December 9, 2012; revised March 8, 2013.

This work was supported by the Universiti Teknologi MARA, Malaysia. Johan@Eddy Luaran is with the Faculty of Education, Universiti Teknologi MARA, Malaysia (e-mail: johaneddy@salam.uitm.edu.my).

Zulkifli Mohamed is with the School of Education and Social Development, Universiti Malaysia Sabah, Malaysia (e-mail: zlkfl@yahoo.com). implement and realize a holistic and world class education system. Education Development Master Plan outlines six cores and one of the main cores which is human capital development, focuses to produce a competent workforce in science and technology. Accordingly, the emphasis in this case can be seen from the program or the steps taken in the Report Card Education Development Master Plan. Among the steps the Ministry of Education has taken for rural schools are (a) allocating 82 million Malaysian Ringgit to provide conference tele-equipment, satellite phone and wireless fax facility to 5,800 urban and rural schools, (b) allocating 113 million Malaysian Ringgit to prepare courseware for teachers and pupils (c) providing Internet access to all school including Government funded Religious School (d) expanding computer laboratories by using cabin concept in low enrolment school.

Based on the Malaysian Education Ministry planning, by year 2010, all 10,000 primary and secondary schools in Malaysia will become smart schools [2]. This means that teachers must equip themselves to master the application of information technology and integrate it in teaching and learning. To achieve this objective, the government allocated 33.4 billion Ringgits to the Ministry of Education in 2007 [3]. The allocation of 10.1 billion Ringgits for information technology-based training programs was to provide schools with computer facilities and Internet access.

Previous studies showed that the government has spent millions of Ringgits just for software licenses. To generate computer labs in schools, the government paid 25 million to Microsoft Corporation in 2001 (for software such as Microsoft Office, Windows 2000 Server, Windows 98 and others). The same amount was paid to Microsoft Corporation in 2002 and 2003 with the expenditure approaching 100 million for three years and the government will pay more than 500 million Ringgit in the coming three years for various licenses for Microsoft products [4].

The government's move to implement teaching and learning of science and mathematics in English in the year 2003 had caused the government to spend 15 millions Ringgits to Microsoft Corporation in 2002 and continuously the amount approached 100 millions [4]. The payments for these licenses will continue to increase with the update version of every Microsoft product. Therefore, it is highly wasteful if teachers can not use it effectively and apply it in the classrooms. It was also found that the minimum application of computers by teachers in a month was less encouraging. The findings also show that teachers often use word processing programs and rarely used database software, multimedia presentation, graphic presentation, electronic mail and web in teaching. Even the scenario today has not changed much as many teachers have yet to master the skill of 
information technology.

Research by [5] indicate that teachers who followed the in-service course for 14 weeks were still incompetence in selecting and using software, planning and designing learning package. This was also supported by [6] who studied 21 teachers in a number of schools around Pahang, Malaysia. The research shows that the teachers' information technology skill was still at the basic level while their knowledge of information technology was at the moderate level. It was also found that the teacher's failure in using ICT in their teaching and learning activities could be attributed to their lack of computer skill [7]. According to [8], this scenario was alarming considering that teaching using information technology would be ineffective if it is conducted by teachers who do not have the necessary information technology skill.

Based on the issues and problems that have been discussed, this study is to determine the skill of primary school teachers especially those teaching in the interior areas, in using information technology. Furthermore, this study will develop a multimedia study package called WEDPI Learning Packages that use ADDIE instructional model with the objective to help teachers to master the application of information technology. WEDPI stands for Microsoft Word, Microsoft Excel, Microsoft Access (ㅁatabase), Microsoft PowerPoint and Internet. Meanwhile ADDIE instructional model refers to Analysis, Design, Development, Implementation and Evaluation.

Therefore, the objectives of this study are to determine the level of skills of primary school teachers in using information technology and to develop a multimedia learning package (WEDPI Package) that could help the weak teachers to learn and increase their skill in information technology.

\section{Methodology}

This is a quantitative study that involved pre and post tests on one group. The study was conducted in primary schools in rural areas in Sabah, Malaysia. This study involved 74 teachers and used a stratified sampling. The teachers involved were divided into three groups using stratified sampling. These groups were less skilled, moderate and skilled. The groups were formed based on the information technology skills test. The groups were formed by the researchers and the teachers who are in the less skilled group were exposed to the WEDPI package for three weeks. After three weeks, a post test was conducted. The information technology skill test was divided into five parts, namely word processing, electronic spreadsheet, database, presentation and the Internet. The items were categorized into three tasks, namely basic operation, manipulation and design. The internal consistency of the instrument for the actual study was calculated. The score of each item was summed up and the KR-20 values show the value of good consistency with each parts recorded above 0.7 .

\section{WedPi PaCKage Design}

The WEDPI Package was developed using the ADDIE model. This is a step by step model consisting of five steps.
The steps are Analyzing, Design, Develop, Implementation and Evaluation. In the analyzing step, the researcher analyzed the needs of the teachers by conducting interviews and a pilot test. The interviews involved two information technology officers, while the pilot test that measured information skill was conducted on 35 primary school teachers. The test shows that there were teachers still unable to master the basic skills of productivity tools. In this research, productivity tools refer to five major computer applications namely word processing, electronic spreadsheet, database, presentation and Internet. The data were supported by the interview with the Information Technology officers. Hence, based on the result and input from the interview, the content of the learning package was drafted and experts' views were taken into consideration.

Based on the data collected and feedback obtained, the team agreed that the learning package should emphasize on five of the major computer applications namely word processing, electronic spreadsheet, database, presentation and the Internet with a minor modification. Selection of topics for each application of information technology was made based on [9]. The content of WEDPI Learning Package was designed to engage the user actively. Each section of interface in this package is not overloaded with information.

The users were also provided with the module of WEDPI Learning package. This can help users to use this package more effectively. The andragogy principles by [10] and constructivism learning principles by [11] were integrated in the design and development of the learning package. Andragogy consists of learning strategies focused on adults. It is often interpreted as the process of engaging adult learners with the structure of learning experience. Meanwhile, constructivism is a philosophy of learning founded on the premise that, by reflecting on our experiences, we construct our own understanding. Therefore, is simply the process of adjusting our mental models to accommodate new experiences.

Furthermore, the designs of multimedia elements such as texts, graphics, audio and videos are easy to understand and also user friendly. For the video elements, Microsoft Office 2003 and Internet Explorer were used as a platform. Fig. 1 and Fig. 2 show the interface of WEDPI package.

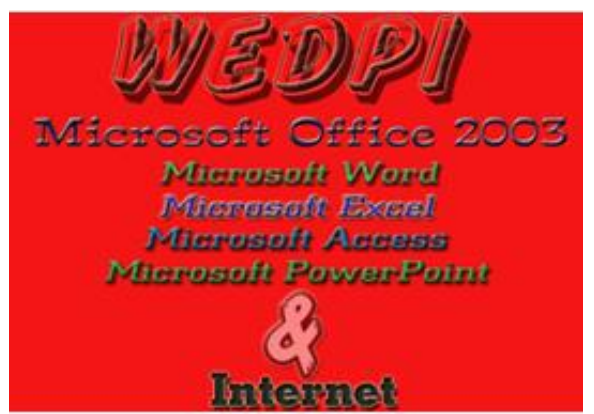

Fig. 1. The opening interface for WEDPI package.

The WEDPI package was developed using Authorware Macromedia version 7.0. The software was chosen because of its flexibility, ease to manage and its ability to support texts, graphics, videos and audio. Other programs that were used in designing the learning package were Adobe Photoshop 7.0, Camtasia Studio 5.0, Microsoft Word 2003, Microsoft Excel 
2003, Microsoft PowerPoint 2003, Microsoft Access 2003, Internet Explorer 6.0 and ScreenCam 3.0. After the WEDPI package was developed, a formative evaluation was conducted. During the formative evaluation, six persons consisting of three teachers and three experts evaluated the learning package. All their comments and feedbacks to improve the learning package were taken into consideration.

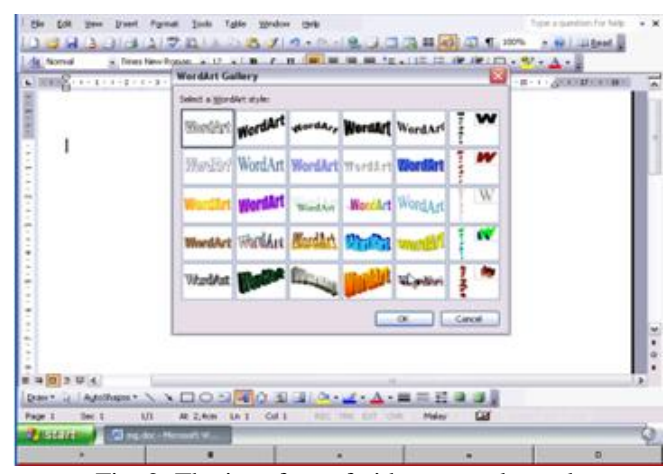

Fig. 2. The interface of video control panel.

During the implementation stage, teachers in the less skilled category were exposed to the WEDPI Learning Package for three weeks. A demonstration on how to use the learning package was made. After three weeks, a post test was conducted. The teachers' scores during the pre and post tests were analyzed statistically using SPSS (Statistically package for social sciences) Version 15.0. The output of t-test is considered summative evaluation for this package.

\section{RESULTS AND DISCUSSION}

The findings in Table I show that the word processing application recorded the most number of teachers with a high level of skill (37 teachers) while the application database recorded the most number of teachers with less skill (47 teachers). The findings of this study are consistent with [5] and [7], which state that the level of information technology skill among teachers is still at a basic level.

TABLE I: SKILLS LEVEL FREQUENCY OF THE RESPONDENTS AGAINST FivE COMPUTER APPLICATION

\begin{tabular}{cccc}
\hline & \multicolumn{3}{c}{ Skill level (n=74) } \\
\cline { 2 - 4 } Computer & \multicolumn{3}{c}{ Less } \\
Application & Skilled & Moderate & skilled \\
\hline Word processing & 37 & 30 & 7 \\
& $(50 \%)$ & $(41 \%)$ & $(9 \%)$ \\
\hline Spreadsheet & 17 & 24 & 33 \\
& $(23 \%)$ & $(32 \%)$ & $(45 \%)$ \\
\hline Presentation & 21 & 19 & 34 \\
& $(28 \%)$ & $(26 \%)$ & $(46 \%)$ \\
\hline Database & 4 & 23 & 47 \\
& $(5 \%)$ & $(31 \%)$ & $(64 \%)$ \\
\hline Internet & 23 & 18 & 33 \\
& $(31 \%)$ & $(24 \%)$ & $(45 \%)$ \\
\hline
\end{tabular}

The above statistical data show that more than $60 \%$ of the teachers do not master application database. This is consistent with [12], [13] which state that this application is not utilized by a large number of teachers because it is less relevant in the teaching and learning process. Meanwhile, word processing application recorded a high number of skilled respondents. The finding is consistent with previous studies [9], [14], [15], which revealed that educators get positive effects by using this application.

At the same time, the teachers' skill in spreadsheet applications supports the previous studies [12], [16] which state that it can assist teachers in teaching as well as managing students' marks. Findings show that the presentation and Internet applications are on the moderate level and they are consistent with [13], [17] and [18] which state that the use of these applications driven by teachers' increasing awareness that they could help in the teaching and learning processes.

A t-tests was conducted to determine whether there were differences between the pre and post tests scores of the teachers' information technology after using the WEDPI package. However the t-test for word processing application (Microsoft Word) is not significant because there were only seven teachers. Based on the scores, it can be concluded that the teachers have the skills in using word processing. Table II show the pre and post t-test results of electronic spreadsheet, presentation, database and the Internet applications after using the WEDPI package.

TABLE II: PRE AND POST T-TEST RESUltS

\begin{tabular}{cccc}
\hline $\begin{array}{c}\text { Computer } \\
\text { Application }\end{array}$ & $\mathrm{t}$ & $\mathrm{df}$ & $\begin{array}{c}\text { Significant level } \\
(2 \text { tail })\end{array}$ \\
\hline Spreadsheet & -11.32 & 32 & $\mathrm{p}<0.001$ \\
Presentation & -9.25 & 33 & $\mathrm{p}<0.001$ \\
Database & -15.73 & 46 & $\mathrm{p}<0.001$ \\
Internet & -9.98 & 32 & $\mathrm{p}<0.001$ \\
\hline
\end{tabular}

The result show that there are significant differences ( $p$ $<0.001$ ) between the mean of the pre and post tests. This shows that WEDPI package was able to assist teachers that are less skilled in rural areas to increase their information technology skill, especially in the application of electronic spreadsheet, presentation, database and the Internet. Although some of the teachers remained less skilled, they however were able to complete more tasks in the post test after using the WEDPI learning package. This shows that the WEDPI learning package was able to help teachers to improve their information technology skills. Overall, the findings are consistent with [19]-[22] that a computer based learning material was able to help to increase the abilities in using information technology.

One of the factors which contribute to the findings is the teachers' awareness in acquiring the information technology skill to upgrade their self competency. The andragogy concept stated by [10] and the constructivism principles [11] integrated in the WEDPI package design also contribute to the findings of this study. The selection of contents for the WEDPI learning package also led to the findings of this study.

\section{CONCLUSION}

Word processing application recorded the most number of teachers with the high level of skill and the application database recorded the most number of teachers with the less 
skill while presentation and the Internet applications are on the moderate level. In the mean time, the WEDPI package was able to assist teachers that are less skilled in rural primary schools to increase their information technology skill especially in the application of electronic spreadsheets, presentations, databases and the Internet. Moreover, the study also revealed that combining adult learning principles and constructivism could contribute in successfully designing and developing a computer based learning material. This study also gives a chance for the less skilled teachers in information technology application, especially those served in rural areas and restrained by distance to use a computer based learning material. At the same time, other skills such as browsing and selecting information from the Internet, developing website and course materials should be emphasized on teachers. Finally the study enables the teachers to blend their skills in teaching and learning. This is in line with our objectives of encouraging teachers to use computer in teaching and learning. However, technology is only an aid in the teaching and learning process. It cannot replace the role of the teacher.

\section{REFERENCES}

[1] Ministry of Education, Mercu Tanda Pendidikan di Malaysia, Kuala Lumpur, Malaysia, AG Grafik, Kuala Lumpur, Malaysia, 2003.

[2] Ministry of Education, Pendidikan di Malaysia, Kuala Lumpur, Malaysia: Percetakan Nasional, 1997.

[3] Treasury of Malaysia. (2007). Ucapan Bajet 2007 oleh YAB Dato Seri Abdullah Ahmad Badawi (Perdana Menteri dan Menteri Kewangan). [Online]. Avaliable: http://www.epu.jpm.my/bajet/bmbajet2007.pdf

[4] S. Saad. (2004). Open Source: Benefits to Education Sector. [Online]. Avaliable:

http://opensource.mimos.y/ourparticipation/slides/20April2004\%200 S\%20Benefits\%20to\%20Education\%20Sector\%20v1.0.pdf

[5] M. Sani, M. Nordin, and M. Roslee, "Budaya ICT di kalangan guru-guru sains dan matematik: Trend dan Isu," Journal Pendidikan, Malaysia, vol. 7, pp. 15-24, 2004.

[6] N. A. Muslim, N. D. Yahya, and N. Abidin, "Persepsi guru-guru terhadap penggunaan teknologi maklumat dan komunikasi," presented at the SITMA, Malaysia, 2006.

[7] M. A. Z. M. Zakaria, B. Aris, and J. Harun, "Kemahiran ICT di kalangan guru-guru pelatih UTM: Satu tinjauan," presented at the 1st International Malaysian Educational Technology Convention, Malaysia, 2008

[8] J. R. Young, "When good technology means bad teaching," Chronicle of Higher Education, vol. 15, no. 12, 2004.

[9] J. F. Patricia and J. G. William, Microsoft Office for Teachers, New Jersey: Pearson Education, 2003.
[10] M. Knowles, The Adult Learner, A Neglected Species, $4^{\text {th }}$ ed. Houston : Gulf Publishing Company, 1990.

[11] B. Aris, R. S. Shariffudin, and M. Subramaniam, Reka Bentuk Perisian Multimedia, Kuala Lumpur, Malaysia: Penerbit Universiti Teknologi Malaysia, 2002.

[12] T. Weiss, "Word processing in the business and technical writing classroom," Journal of Computers and Composition, vol. 5, no. 2, pp. 57-70, 2003.

[13] C. Jewitt, Technology, Literacy and Learning: A multimodal approach, New York: Routledge, 2006.

[14] J. L. Morrison, Teacher Use Computers, Victoria Park: Napier Publication, 2000.

[15] S. L. Wong, Development and Validation of an Information Technology (It) Based Instrument to Measure Teacher's It Preparedness, University Putra Malaysia, Kuala Lumpur, Malaysia, 2002.

[16] J. R. M. Paul and C. Kaiser, "Do women live longer than men? Investigating graveyard data with computers," Learning and Leading with Technology, vol. 8, pp. 13-15, 2000.

[17] M. Vallance and P. A. Towndrow, "Towards the 'informed use' of information and communication technology in education: a response to Adams' 'PowerPoint', habits of mind, and classroom culture," Journal of Curriculum Studies, vol. 39, no. 2, pp. 219-227, 2007.

[18] W. Buckley and A. Smith, "Application of multimedia technologies to enchance distance learning," Re:View, vol. 39, no. 2, pp. 57-65, 2008.

[19] R. Jamaludin, Internet dalam Pendidikan, Pulau Pinang, Malaysia: Penerbit Universiti Sains Malaysia, Malaysia, 2007.

[20] Y. S. Tugba, Computer in Education (Annual Edition 04/05) [Student Teachers Perceptions of Instructional Technology: Developing Materials Based on a Consructivist Approach], Guilford: McGraw Hill, 2004

[21] S. L. Huann and L. C. Houn, Computer in Education (Annual Edition 04/05) [Using Computers to Support a Beginning Teachers Professional Development], Guilford: McGraw Hill, 2004.

[22] K. H. Seng and B. J. Fraser, "Using classroom psychological environment in the evaluation of adult computer application courses in singapore," Peer Review Journal: Technology, Pedagogy and Education, vol. 17, no. 1, pp. 67-81, 2008.

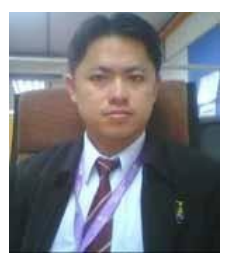

Johan@Eddy Luaran was born in Tuaran, Sabah, Malaysia on June 18, 1979. He obtained his degree from University Science of Malaysia (USM) in 2001 in Chemical Engineering. Before joining the teaching profession, he completed his diploma in education at the Teacher's Training College in Keningau in 2002. $\mathrm{He}$ earned his master in education from University Technology Malaysia (UTM) in 2006 and completed his Ph.D. from Universiti Malaysia Sabah, Malaysia in 2010. Upon completing his Ph.D., he begins his career as a lecturer at the Faculty of Education, Universiti Teknologi MARA, Malaysia. His area of specialization was instructional technology and computer in education and he was a member of International Association of Computer Science and Information Technology (IACSIT). He has published one chapter in books, one indexed journal paper and 6 conference proceedings at the national and international level. 